2. Bentall H, De Bono A. A technique for complete replacement of the ascending aorta. Thorax. 1968;23:338-9.

3. Cooley DA, De Bakey ME. Resection of entire ascending aorta in fusiform aneurysm using cardiac bypass. JAMA. 1956;162:1158-9.

4. Blanco G, Adam A, Carlo V. A controlled surgical approach to annulo-aortic ectasia. Ann Surg. 1976;183:174-8.
5. Cabrol C, Pavie A, Mesnildrey P, Gandjbakhch I, Laughlin L, Bors V, et al. Long term results with total replacement of the ascending aorta and reimplantation of the coronary arteries. J Thorac Cardiovasc Surg. 1986;91:17-25.

6. Kouchoukos NT, Wareing TH, Murphy SF, Perrillo JB. Sixteen-year experience with aortic root replacement. Results of 172 operations. Ann Surg. 1991;214: 308-18; discussion 318-320.
See Article page 1063.

\section{Commentary: Redo root surgery: Complicated, but feasible}

\author{
T. Brett Reece, MD
}

Aortic root replacement in the setting of previous cardiac surgery can be a formidable undertaking, as described by the authors from Toronto General. At times, identifying the annulus, or even something strong enough to hold annular stitches, can be difficult to recognize. The most intimidating cases can be those that had previous root manipulation, especially given the potential combination of coronary button immobility and tissue friability. Overall, Mazine and colleagues ${ }^{1}$ demonstrate the important considerations required for the optimal care of these difficult patients.

The authors should be praised for demonstrating the risk involved with these procedures. For this cohort, they observed a 30-day mortality of $7.8 \%$. The in-hospital reoperation rate was $14 \%, 2.3 \%$ of which were for bleeding or tamponade. Importantly, the permanent pacemaker rate was $18.8 \%$. Cleary, this rate is above the rate of primary valve or root replacement but speaks to the anatomic difficulties of identifying adequate "annular" tissues to which to sew the conduit. These outcomes are commendable and should be used as an example of what can be achieved with this operation.

The authors eloquently describe important variations required to address redo root anatomy, including both annular reconstruction and alternate coronary implantation techniques. Of note from this study, the authors did not identify extensive

From the Division of Cardiothoracic Surgery, Department of Surgery, University of Colorado School of Medicine, Aurora, Colo.

Disclosures: Author has nothing to disclose with regard to commercial support.

Received for publication Jan 25, 2020; accepted for publication Jan 26, 2020; available ahead of print Feb 7, 2020.

Address for reprints: T. Brett Reece, MD, Department of Surgery, University of Colorado School of Medicine, 12631 E 17th Ave, MS C310, Room 6601, Aurora, CO 80045 (E-mail: Brett.reece@ cuanschutz.edu).

J Thorac Cardiovasc Surg 2021;162:1073-4 0022-5223/\$36.00

Copyright (c) 2020 Published by Elsevier Inc. on behalf of The American Association for Thoracic Surgery

https://doi.org/10.1016/j.jtcvs.2020.01.074

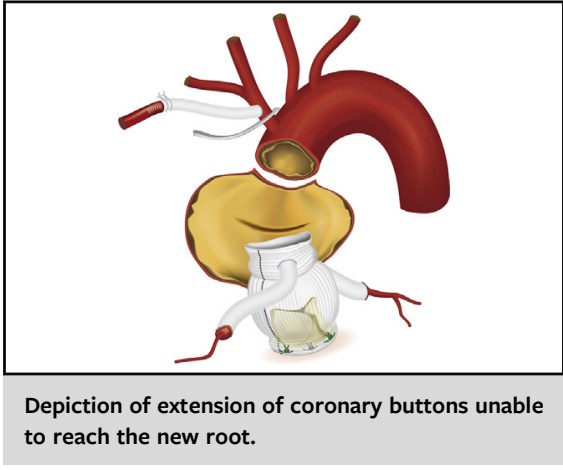

CENTRAL MESSAGE

Aortic root replacement in the setting of previous cardiac procedures requires extreme diligence and a degree of flexibility to deal with common anatomic degeneration to optimize outcomes.

annular reconstruction from endocarditis as a risk of mortality or morbidity. Among other groups, this degree of reconstruction certainly complicates outcomes, but the authors' approach will be a goal for all surgeons embarking on these reconstructions. Although the need for alternative approaches to direct coronary reimplantation arose as a significant risk for significant complications, they were inevitable in $20 \%$ of patients in this series. The approach used was extension rather than a Cabrol-type approach. The authors' bias had been that the Cabrol graft compromises patency; however, optimizing the length of extension and even the conduit used remains evasive for many surgeons. Essentially, the anatomic variations of redo operations can be difficult to deal with, but with experience, the patients can be approached with acceptable but increased risk over primary operations.

Redo root operations require readiness for alternative reimplantation approaches. While these approaches carry more risk, these patients may not be otherwise 
reconstructable. Identifying these issues and being mentally prepared to provide alternative methods of reconstruction are critical for patient outcomes.

\section{Reference}

1. Mazine A, David TE, Lafreniere-Roula M, Feindel CM, Ouzounian M, et al. Early outcomes of the Bentall procedure after previous cardiac surgery. J Thorac Cardiovasc Surg. 2021;162:1063-71. 